\title{
The EU and Local Governments
}

\section{Mustafa T. Karayiğit ${ }^{1}$}

\begin{abstract}
The impact of European integration on the national legal systems had primarily been examined until the early 1990s in terms of national governmental aspects within the context of evergreen issue of delimitation of competences. This confinement could be discerned in the formulation of theories about the EU integration models which have centred around state-centric and supranational conceptions (based either on intergovernmentalism or neo-functionalism). This also could be noticed even in the analyses of the principle of subsidiarity made in the wake of its introduction to the EC Treaty that were confined to the issue of delimitation of competences between the EU institutions and national governments merely. As correctly described by D'Atena, the European system was suffering from the federal blindness and indifference towards the existence of subnational authorities and was being solely occupied with central levels of governments. (D’Atena, 2005, p. 8)
\end{abstract}

Key Words: EU, Local Governments, Integration, Subranational

\section{Introduction}

The impact of European integration on the national legal systems had primarily been examined until the early 1990s in terms of national governmental aspects within the context of evergreen issue of delimitation of competences. This confinement could be discerned in the formulation of theories about the EU integration models which have centred around state-centric and supranational conceptions (based either on intergovernmentalism or neo-functionalism). This also could be noticed even in the analyses of the principle of subsidiarity made in the wake of its introduction to the EC Treaty that were confined to the issue of delimitation of competences between the EU institutions and national governments merely. As correctly described by D'Atena, the European system was suffering from the federal blindness and indifference towards the

\footnotetext{
${ }^{1}$ Assoc. Prof., Marmara University, EU Institute
} 
existence of subnational authorities and was being solely occupied with central levels of governments. (D’Atena, 2005, p. 8)

It was then realised that accumulation of EU law adopted on the basis of judicially extended notion of competences conferred by the Member States has more and more legal, political and economic influences on the subnational (regional/local) levels. Pursuant to a sufficient maturity of integration the focus of analysis of the impact of that integration was accordingly extended to its subnational aspects, since the game was no longer between the supranational and national central levels. Therefore awareness of subnational governments about the impact of European integration on them as being its components and (a)symmetrical interdependence of supranational, national and subnational levels for the good governance of the EU emerged. A new theory was accordingly supplemented, namely the concept of multi-level governance, to depict the true structure of the European integration. With the Europeanisation, which signifies an incremental process reorienting the domestic politics, EU political, legal and economic dynamics become part of the organisational and daily working logic of national domestic politics and policy-making. (Ladrech, 1994, pp. 69-88) Regional and local levels have therefore gradually involved in the European construction through intra or extra-State channels. In addition to the old form of hierarchical governing, the network of politics has been aggregated not only through the interdependence and interaction between supranational, national, regional and local levels, but also through the growing interdependence between public authorities and non-public actors at various levels under the trend of governance. (Panara, 2015, p. 1) In that respect, the notion of governance arises as a new mode of governing which is distinct from the hierarchical model and reflects a cooperative mode of governing where non-state players are involved in public decision-making through public or private networks. (Panara, 2015, p. 1) In this construction, coexistence, interdependence, interaction, co-evolution, collaboration and cooperation thus become the fashion of the day.

Within the context of European integration, through the involvement of local governments into the constitutional structure of the EU under the principles of democratic participation and subsidiarity, European constitutionalism has been reinforced within the framework of three dimensions: 1) Top-down approach to the implementation of EU law and principles in the regional/local levels; 2) Bottom-up 
participation of local governments via intra or extra-Member State channels in the supranational decision-making; 3) Bottom-to-bottom integration between local authorities through transnational networks. In the article, the impact of European integration on local governments will be analysed within these three dimensions after the configuration of the approach of the EU towards local governments in order to place the status of local governments in that construction.

It should be notified that European integration does not occur in a vacuum, but undergoes with and/or within co-existing divergent and convergent trends such as governance, globalisation, decentralisation, centralisation, marketization through negative and positive integration, market liberalisation, privatisation, New Public Management, mobilisation, democratisation and urbanisation which all also have great influence on subnational constructions.

\section{The Approach of EU Law towards Local Governments}

The constitutional structure of the Member States is not identical and signifies different patterns ranging from unitary to federal systems. Sub-national authorities have different levels, status, structures, powers and responsibilities across the EU or even in the same Member State varying from region to region. (Panara, 2015, p. 6) Even within these different structures, there was a trend of centralisation strengthening the centre at the expense of the regional and local which was the case in some traditional centralised unitary states such as the United Kingdom and Ireland. (Loughlin, 2004, p. 393) A decentralisation trend has also taken place across Europe since 1970 such as becoming operational of the Italian Regions in 1970 and enhancement of the powers of the regions and of the local authorities in 2001, with the Italian constitutional reform, by strengthening the regions and giving the state some federalist characteristics and becoming a regionalised unitary state with special regions, the full transformation of Belgium into a federal state in 1994, the progressive creation of a unitary decentralised state in France since 1982, the introduction of devolution in the UK to Scotland, Wales, and Northern Ireland in 1998 and the constitutional reforms in Germany strengthening the position of the Länder and subnational territorial communities in 1994 and 2006. In accordance with 1978 Constitution Spain created the autonomic state, creating 17 autonomous communities and providing autonomous communities to gain more powers at the expense of the central government. Portugal 1976 Constitution granted 
autonomous status to Azores and Madeira. The Scandinavian countries (Denmark, Finland and Sweden) have been decentralised unitary states with a strong welfare state model whose local government play an important role in the construction. These institutional reforms have been carried out for different reasons such as being a part of the neo-liberal agenda of the 1980s, which involves transferring responsibilities and tasks from central governments to other levels of administration, as modernising systems of public administration which had become over-centralised, inefficient and away from citizens and as attempts to enhance regional and local democracy. (Panara, 2015, pp. 157-158; Panara and Varney, 2013, p. XVII; Vetter and Kersting, 2003, p. 16; Loughlin, 2004, pp. 393-394; D’Atena, 2005, p. 9)

In these different structures, the notion of local government comprises all the authorities which are belonging to the local self-government, signifying all sub-regional territorial authorities enjoying some degree of autonomy from both the national and regional government and are elected by the local communities. (Panara and Varney, 2013, p. XIX) In that regard, municipalities or communes are to be considered as local level constructions. There is predominantly a significant difference between the regional and local governments: whereas regional governments might have the legislative powers like the national parliament, local governments are typically vested only with administrative powers, including the power to pass hybrid forms of legislation such as bylaws and ordinances, (Panara, 2015, p. 6) which creates differences when transposing directives into the national legal systems.

How is the approach of the EU towards these variable structures? The Union is not only neutral, but also respectful towards the construction of division of domestic powers and responsibilities within the constitutional systems of the Member States. It has been settled case law that "when provisions of the Treaties or of regulations confer powers or impose obligations upon the Member States for the purposes of the implementation of EU law, the question of how the exercise of such powers and the fulfilment of such obligations may be entrusted by Member States to specific national bodies is solely a matter for the constitutional system of each State". (Case C-156/13, Digibet, 2014, para. 33; Joined Cases 51/71 to 54/71 International Fruit Company, para. 4) 
This case law has recently been codified in primary EU law with the Lisbon Treaty, the protection of the constitutional identity of the Member States has attained to become a written constitutional principle of the EU in order to provide unity in diversity. According to Article 4(2) of the Treaty on the European Union (TEU), "The Union shall respect the equality of Member States before the Treaties as well as their national identities, inherent in their fundamental structures, political and constitutional, inclusive of regional and local self-government." The Preamble of the Charter of the Fundamental Rights of the EU also states that "The Union contributes to the preservation and to the development of these common values while respecting the diversity of the cultures and traditions of the peoples of Europe as well as the national identities of the Member States and the organisation of their public authorities at national, regional and local levels" In that regard, the Union shall respect the local/regional autonomy which constitutes an essential element of the constitutional identity of the Member States as also exemplified in the ratification of the European Charter of Local Self-Government of the Council of Europe by all Member States. (Panara, 2015, pp. 60-61)

Because of that approach European integration impact national subnational governments within the framework of national systems. For that reason, domestic adaptation to European integration occurs with national colours in which national characteristics continue to play a role in shaping influences and outcomes. (Risse, Cowles and Caporaso, 2001, p. 1)

It should nonetheless be declared that there is a general belief arising in the new accessed Member States that even though the EU does not impose any model of regional organisation for the candidate states, the Commission favours decentralisation and democratised regional governance whose regional structures are democratically elected, self-governing, having substantial financial and legal autonomy, and having administrative units to be able to be partners of the Commission in the conduct of the EU regional policy. (Baun and Marek, 2006, pp. 409-428) It seems to have purpose further than supporting regional construction of post-Socialist Member States which had very unitary characteristics during the Soviet regime within the context of the preferences of the Commission as being more autonomous supranational institution than the national governments. 


\section{The Obligations of Local Governments Arising from EU Law}

The EU has no executive branches and apparatus in the Member States in order to implement EU law, but relies primarily upon on the shoulders of the Member States for the implementation of EU law. The local governments as other levels of the EU construction are obliged under the principle of duty of cooperation to implement EU law and fulfil obligations arising from EU law. Depending on the constitutional system of each Member State, the local governments have varied degree of responsibility for the implementation of EU law. Each Member State is therefore free to arrange its domestic powers and delegate some of them to its domestic authorities how it considers and to implement directives by means of measures adopted by regional or local authorities. "That division of powers does not however release it from the obligation to ensure that the provisions of the directive are properly implemented in national law." (Joined Cases 227 to 230/85 Commission v Belgium, 1988, para. 9)

Estimation of the percentage regarding the involvement of regional and local authorities in the implementation of EU law in the national legal systems varies from scholar to scholar. For instance Christiansen and Lintner assert that 70 and 80 percent of EU policies require implementation by regional and local authorities, (Christiansen and Lintner, 2005, pp. 7-13) Guderjan argues that "in Germany about 80\% and in England approximately $50 \%$ of European legislation is implemented by subnational authorities." (Guderjan, 2015, p. 5) As correctly ascertained by Callanan, these proportions can be expected to vary considerably from Member State to another depending on the division of powers and responsibilities between the domestic levels and so the degree of decentralisation in the member state concerned. (Callanan, 2012, pp. 349-420) In some Member States the responsibility for transposing directives into national law or adopting implementing measures lies entirely with the national government, in some this role is also shared with regional and local authorities. For instance in the UK, since local government has no significant power to legislate and thus local authorities do not have a significant role in the legislative implementation of EU law, legislative implementation all is carried out at the level of national government. This assertion is valid with regard to directives, which generally require national implementing measures having statutory quality. Generally lack of legislative powers of the local governments precludes their involvement into the adoption of measures transposing directives. The local governments nevertheless may involve implementation 
of measures adopted by the central or regional governments for transposing directives within the framework of domestic delimitation of powers.

The duties of local governments in implementing EU law go beyond that. In that respect, local authorities play a significant role in the day-to-day implementation of EU law related to their functions touched upon by EU legislations. (Varney, 2013, pp. 353354) The day-to-day implementation duty of municipalities primarily arises with their quality of being also an EU public authority. Therefore, local authorities are under the obligation to implement EU law through the remedies of direct effect and indirect effect, even for directives in terms of which the central or regional government has not adopted measures transposing. In that regard, local authorities are enabled and even obliged by EU law to set aside incompatible national measures in order to implement EU law or to interpret national measures in compliance with EU law. Day-to-day implementation is valid for entire corpus of EU law (i.e. primary and secondary EU law, and agreements concluded by the EU) touching upon municipal functions. Accordingly, in addition to fields which could be easily expected to fall within the municipal activities such as local transportation, waste management, regional and cohesion policy and environment, in the fields of free movement, state aid, public procurement, competition and services of general economic interest, local governments, as employers, service providers, urban planners, as monitoring and enforcing agents, as economic operators have to comply with acquis within their jurisdictions. (Hessel, 2006, pp. 91-110; Kaiser, 2005, pp. 367-380)

The EU has also great impact on municipalities when they exercise official authority, especially within the scope of their supervisory functions, since municipalities are subject to provide reports under EU law and harmonised standards when making inspections in fields such as environmental protection, food hygiene and the common agricultural policy. (Persson, 2013, p. 324)

The entire process which has been explained actually depicts "the domestication of Europe" (Wallace, 2000, pp. 156-157) in the local levels and deep transformation of the Member States from within which has been occurring to great extent within the framework of constitutional, political and administrative variables in the Member States and the regional constructions within the same Member State. 
EU law also bestows rights on the EU citizens to vote and stand as a candidate in local elections. According to Article 22(1) Treaty on Functioning of the European Union (the TFEU), "Every citizen of the Union residing in a Member State of which he is not a national shall have the right to vote and to stand as a candidate at municipal elections in the Member State in which he resides, under the same conditions as nationals of that State." Local governments therefore under the obligation to actualise the rights of the EU citizens to use their rights to vote and stand in local elections.

With regard to legal protection of local governments against EU acts, case law has state-centric conception with regard to judicial procedure of action for annulment and does not bestow any privileged locus standi further than that given to natural and legal persons in EU law. In other words, privileged locus standi to bring any case before the Court of Justice of the EU for the legality review of EU acts is given merely to the national governments. Therefore, local governments have to meet the requirements of individual and direct concern to acquire locus standi for direct actions before the Court of Justice of the EU. Under Article 8 of Protocol (No 2) On the Application of the Principles of Subsidiarity and Proportionality, "The Court of Justice of the European Union shall have jurisdiction in actions on grounds of infringement of the principle of subsidiarity by a legislative act, brought in accordance with the rules laid down in Article 263 of the Treaty on the Functioning of the European Union by Member States, or notified by them in accordance with their legal order on behalf of their national Parliament or a chamber thereof." The expression a chamber thereof comprises also the national legislative parliaments that represent local and/or regional sub-state authorities. (Panara, 2015, p. 41) Local governments may be judicially protected against EU legislative acts which infringe the principle of subsidiarity by actions brought by the Member States on behalf of a chamber of their parliament which represents local governments.

The principle of State liability, which is significant not only to provide reparation for individuals sustained from loss or damages caused by public authorities and effective legal protection of their rights, but also to ensure effectiveness of EU law, was established in Francovich by the Court of Justice of the European Union (the CJEU). (Joined Cases C-6/90 and C-9/90 Francovich, 1991) (The CJEU perceives the Member States as a single entity as in the case of international law under which a State within the context of liability for breach of an international commitment will be viewed as a single 
entity. (Joined Cases C-46/93 and C-48/93 Brasserie du Pêcheur, 1996, para. 32-34) Accordingly, the Member States might be held responsible in the infringement procedure for the acts or omission of their regional/local authorities which cause damage to individuals under the principle of State liability. (Case 97/81 Commission v Netherlands, 1982; Case 365/97 Commission v Italy, 1999; Case 147/00 Commission v France, 2001)

\section{Participation of Local Governments in the EU Decision-Making}

In the Preamble of the TEU, the emphasis is on "the process of creating an ever closer union among the peoples of Europe, in which decisions are taken as closely as possible to the citizen in accordance with the principle of subsidiarity". According to Article 5(3) TEU "Under the principle of subsidiarity, in areas which do not fall within its exclusive competence, the Union shall act only if and in so far as the objectives of the proposed action cannot be sufficiently achieved by the Member States, either at central level or at regional and local level, but can rather, by reason of the scale or effects of the proposed action, be better achieved at Union level." The Lisbon Treaty introduced regional and local level into the conception of delimitation of competences under the principle of subsidiarity.

According to Art. 16(2) TEU, "The Council shall consist of a representative of each Member State at ministerial level, who may commit the government of the Member State in question and cast its vote". The Treaty ${ }^{2}$ accordingly allows the participation the subnational authorities (even though in practice local governments are excluded from representation (D'Atena, 2005, p. 13)) in Council meetings insofar as the Member State provides arrangements for their involvement depending on its structure of the delimitation of powers and responsibilities between the domestic authorities. Therefore, local participation in the Council also depends on the national attitude towards the involvement of subnational authorities in the Council, which is the primary legislative institution of the EU.

Local governments realised as explained above that their activities have been increasingly touched upon by EU legislation and policies. Municipalities also realised that they may involve in EU decision-making in order to reflect their interest at the supranational level whose legislation in the end has an effect at the local level. This

\footnotetext{
${ }^{2}$ It was the Maastricht Treaty which allowed this by removing the reference to national governments.
} 
epitomises the efforts of influenced to influence influencing. The EU establishes a framework for regional and local participation in the EU, but, in line with its neutral and respectful attitude, cannot oblige the Member States to create participation channels for the subnational authorities or to use those prompted at the supranational level and, in accordance with the 'united in diversity' motto, cannot impose uniform patterns to the Member States. (Panara, 2015, p. 54) According to some scholars, national governments even remain strong gatekeepers for local activities with a power to close off the European arena to them and so the capability of local authorities to effectively participate in EU decision-making depends on the constitutional and political arrangements within the Member States. (Guderjan, 2012, pp. 105-128)

However in practice the participation of local governments in the EU decisionmaking is not confined to the intra-national channels or internal constitutional, political and representative arrangements of the Member States merely. Their participation nevertheless goes beyond the representative mechanisms arranged by the national governments. There is not only (indirect) intra-State routes and channels such as participating in national decision-making on EU negotiations, participation in the national delegation for EU negotiations, representing the Member State in the Council, representing regional and local authorities in the Committee of the Regions, appointing a subnational attaché to the national permanent representation to the EU, but also extraState (direct and unmediated (Jeffrey, 2000, pp. 1-23)) routes and channels to the supranational decision-making such as establishing networks with the supranational institutions, influencing the Members of the Committee of the Regions and establishing offices in Brussels. (Van den Brande, Bruyninckx and Happaerts, 2012, pp. 12-16) Even though national governments remain significant and the main route, they no longer have a monopoly in EU policy-making over issues influencing regional and local structures, nor are gatekeepers for national actors who try to reach to the supranational level, nor play the sole critical role of intermediary between supranational and subnational levels, nor are in the position to exclude subnational authorities from EU policy-making processes or control their entry to such processes. (Hooghe and Marks, 1996, pp. 73-91; Jeffrey, 2000, pp. 1-23; ; Hooghe and Marks, 2001, p. 3; Rob de Rooij, 2002, pp. 447-467) In other words, local participation in the EU is not only channelled by national authorities and filtered by national mechanisms, which coordinate the positions of domestic authorities in order to formulate the national position in the supranational 
decision-making, there accordingly exist more direct participation channels at the supranational level such as the Committee of the Regions. (Panara, 2015, p. 66) In that regard, one of the most important consequences of the European integration is described by Hooghe and Marks as the multiplication of extra-national channels for the subnational political activity. (Hooghe and Marks, 96, pp. 73-91)

Even though countries remain basically faithful to their state and national political and administrative traditions, these traditions have been in constant change and adaptation under the influence of globalisation, Europeanisation, societal and technological change (Loughlin, 2004, p. 388) and independent role of actors from national government emerges. (Hooghe and Marks, 2001, p. 3) In that respect, for instance in some countries such as Germany, France, Spain and to some extent Great Britain, municipalities consider the EU as a means to by-pass their central governments. (John, 2000, pp. 877-894) Supranational institutions and policies thus transfer ideas and working practices to the regional and local authorities which enable local decisionmaking to move away from national and hierarchical forms of politics toward more negotiated, cooperative and interdependent practices. (John, 2001, p. 71) It should not nevertheless be overlooked that subnational mobilisation has produced a change in the structure of domestic authoritative decision-making and in the dynamics of intra-state relationships nevertheless to great extent within the framework and logic of the Member States. (Jeffrey, 2000, pp. 1-23)

As another reason for bottom-up dimension of European integration in terms of the local governments, there are EU funds for local governments such as European Regional Development Fund, European Social fund, Creative Local Growth Fund, INTERREG, Leader+, Urbact and Life, which draw their attention for various purposes. Through the structural funds the EU has been promoting urban development and social, economic and territorial cohesion across the EU. To obtain money out of the EU funds still seems to be main or at least a significant reason of local authorities to deal with the EU level. (Van Bever and Verhelst, 2013; Sutcliffe and Kovacev, 2005)

Furthermore, it is the duty of EU institutions to take into account regional and local dimensions. According to Article 2 of Protocol (No 2) On the Application of the Principles of Subsidiarity and Proportionality, "Before proposing legislative acts, the 
Commission shall consult widely. Such consultations shall, where appropriate, take into account the regional and local dimension of the action envisaged."

The Committee of the Regions was established by the Maastricht Treaty. It has advisory role with regard to formulation and implementation of EU law which has domestic effects. Article 300(3) TFEU declares that the Committee "shall consist of representatives of regional and local bodies who either hold a regional or local authority electoral mandate or are politically accountable to an elected assembly." As being an EU assembly of regional and local representatives, the Committee's composition of national representatives is determined in accordance with the structure of domestic subnational levels. In that respect, in most of the Member States the national government has domination on the selection of (sub)national representatives (Hooghe and Marks, 1996, p. 73-91) and proportion of regional and local representatives. Both under Article 13(4) TEU and Article 300(1) TFEU, the European Parliament, the Council and the Commission shall be assisted by the Committee of the Regions acting in an advisory capacity and exercising advisory functions. According to Article 307 TFEU the Committee shall be consulted by these institutions mentioned "where the Treaties so provide and in all other cases, in particular those which concern cross-border cooperation, in which one of these institutions considers it appropriate."

The Committee of the Regions is to be consulted in the fields which might have influences on the subnational levels. Consultation with the Committee of the Regions is required in policy-making for the EU institutions in the field of transport (Article 91(1) TFEU and Article 100(2) TFEU) ; employment (Articles 148(2) and 149 TFEU); social policy (Article 153(2) TFEU); the European Social Fund (Article 164 TFEU); education, vocational training, youth and sport (Articles 165(4) and 166(4) TFEU); culture (Article 167(5)TFEU); public health (Article 168(4) and 168(5) TFEU); the establishment and development of trans-European networks in the areas of transport, telecommunications and energy infrastructures (Article 172 TFEU); economic, social and territorial cohesion (Articles 175, 177 and 178 TFEU); environment (Article 192 TFEU); and energy (Article 194(2). The Committee of the Regions also functions as a channel for the dissemination of information to subnational levels and to the public.

The Committee of the Regions favours multilevel governance as coordinated action by the authorities of all levels in accordance with the principles of subsidiarity, 
proportionality and partnership, based on partnership ${ }^{3}$ and aimed at drawing up and implementing EU policies. The Committee supports subnational authorities' participation in the EU decision-making and accordingly regards multilevel governance not as simply a question of translating European or national objectives into local or regional action, but also as a process for integrating the objectives of local and regional authorities within the EU strategies. ${ }^{4}$ (The Committee of the Regions, 2009, p. 6-7)

Under the procedure of action for annulment the Committee of the Regions has locus standi before the CJEU for the purpose of protecting its prerogatives. In accordance with Article 8 of Protocol (No 2) On the Application of the Principles of Subsidiarity and Proportionality the Committee of the Regions may bring actions on grounds of infringement of the principle of subsidiarity against legislative acts for the adoption of which the TFEU provides that it be consulted.

As an extra-state channel, representation in Brussels is made through both transnational associations and networks of subnational authorities and individual/collective offices of subnational authorities which may interact each other. Permanent representation offices have been established in Brussels by individual and collective regions/municipalities or association of municipalities such as the Council of European Municipalities and Regions (CEMR), the Assembly of the European Regions (AER), Eurocities, the Union of the Baltic Cities (UBC), CEEC-LOGON; European Cities and Regions Networking for Innovative Transport Solutions (POLIS), Local Government International Bureau (LGIB). They are for the purposes of lobbying, obtaining European funds, gathering information, establishing networks with the supranational institutions and forming transnational alliances, cooperation and partnership with their transnational counterparts. They establish working groups and special committees and organise conferences and symposiums to improve awareness of their interests and concerns and to make connections with institutions and their counterparts. They establish formal and informal contacts with the officials of the institutions, members of the European Parliament, members of the Committee of the Regions, national representatives in order to influence EU decision-making by articulating local interests and getting information from the first hands and to acquire EU funds for regional

\footnotetext{
${ }^{3}$ The notion of partnership epitomises cooperative and collaborative aspect rather than hierarchical one.

${ }^{4}$ The Committee of the Regions, White Paper on Multilevel Governance, 30 November 2009.
} 
development. Offices also coordinate the work of national delegations for the Committee of the Regions. (Tatar, 2011, pp. 379-407) The degree of autonomy, development, size of local authorities and political and administrative culture are factors determining the decision-making capabilities of the local governments at the EU level.

Local participation is in fact supported by the Commission in order to enhance political legitimacy of the EU through strengthening direct mechanisms of participatory democracy for subnational governments. (Longo, 2011, pp. 21-50) It pulls local authorities to participate in EU decision-making which is useful to use them as sources of information and expert advice to facilitate the development of policies. (Sutcliffe and Kovacev, 2005; Kern and Bulkeley, 2009, pp. 309-332) Offices also increasingly become interlocutors of the EU institutions and bodies for evaluating the impact of draft policies at the subnational levels. (D'Atena, 2005, p. 41) Accordingly, as being the watchdog of the $\mathrm{EU}$, the Commission also benefit from the subnational governments which are the ultimate implementers of EU legislation not only as a sensor for their reflex and as a sensor or source of information within the context of its supervision function for the status of implementation of these regulations by the subnational authorities. Bottom-up networks are thus to be complemented by top-down networks fostered by the Commission especially within the economic, social and territorial cohesion policy.

Through the direct local representation and participation, democratic deficit in the supranational level to some extent is therefore inhibited and legitimacy and effectiveness of the EU is improved by making the EU not so remote and aloof.

\section{Down-to-Down Integration in the EU between Local Governments}

Vertical top-down and bottom-up integration or constitutionalisation is to be complemented and completed via down-to-down dimension in order to combine and integrate local and regional structures each other. Local authorities' networks take two forms as either being lobby networks for the supranational level decision-making such as Eurocities or being policy-oriented thematic schemes to cooperate in different fields such as environment, public transportation, services of general economic interest etc. (van der Heiden, 2010) It reflects bilaretal/multilateral and long/short terms relationships and constitutes the horizontal dimension of European integration to be carried out mostly together with vertical local mobilisation for the purpose of development of local authorities, competition within the single market, improvement of 
prosperity, fostering of administrative capacity, enhancement of the quality in public services or reduction of the costs of services of general economic interest. (C-480/06 European Commission v Federal Republic of Germany, 2009)

A trend of more specialised municipal networks stem from the similar problems confronted and creation of such institutions facilitating transnational policy learning becomes a strategy in developing and disseminating good practices and new policy concepts. ${ }^{5}$ Through policy transfer, sharing of best practices, dissemination of good examples, mutual learning and horizontal convergence, horizontal networks, citytwinnings, inter-municipal cooperation and partnership provide synergy, cultural interconnection and horizontal win-win arrangements between transnational counterparts and in the end promotion of horizontal European integration. Local governmental networks are also subsidised by the EU funds.

\section{Conclusion}

Discussions endure regarding whether Europeanisation strengthens subnational authorities by causing central governments to lose control; or weakens them with their regional autonomy by undermining legal and constitutional arrangements; or has no substantial effects and so makes no difference on them by keeping the central governments as gatekeepers which accordingly rules out the independence of subnational governments in expressing their voice. (Risse, Cowles and Caporaso, 2001, p. 2; Fleurke and Willemse, 2007, pp. 69-88) It is obvious that European integration has substantial impacts on subnational governments. The extent of that influence is nevertheless being contingent upon different factors. It is to be analysed in the particularity of each subnational government, since it may vary from a Member State to another and even from one region in that Member State to another. The influence of European integration occurs within and/or without the framework of the Member States (i.e. through the converse intra-State and extra-State channels). To be precise, the intra/extra-State channels which subnational authorities use for the participation to the EU decision-making conversely signifies the mirror effect how the European integration has influences on these subnational authorities through. The European integration has influences on the subnational authorities within/without the framework of the Member

\footnotetext{
${ }^{5}$ Kristine Kern and Harriet Bulkeley, "Cities, Europeanization and Multi-level Governance: Governing Climate Change through Transnational Municipal Networks”, 47(2) Journal of Common Market Studies 309-332, 2009.
} 
States. Europeanisation thus epitomises an amalgamation of different influences on different subnational authorities depending on different socio-economic, political, territorial and managerial factors such as the constitutional and political system of each Member State, administrative structure of the Member State, the domestic allocation of competences and responsibilities, so the scope of the powers and responsibilities of the local government in that Member State, autonomy of the local government in that construction, political and administrative culture, its population, socio-economic development and geographical location.

With all these differences, this is what the European integration, based on the principles of unity in diversity, an ever closer Union among the peoples of Europe, does actually mean in order to make the EU a construction of all's. There is no unnecessary uniform imposition on the constituting parts of the EU and the entire transformation is a combination and balance of uniformity and diversity. This is what the EU polity is with its variable components and the characteristics of being multilateral, multi-framework, multipurpose, intertwined, multileveled, multi-layered, heterogeneous and pluralistic. That is why, all the proponents of the European integration theories may find selective evidences in the European structure either to approve their theories or to refute others.

It should be re-emphasised that local governments with their roles, their quality of also being EU bodies, are to implement EU law and policies depending on the scope of their powers and responsibilities within their jurisdictions. Obligations arising from primary and secondary EU law signifies that to some extent autonomy of local governments has been restricted, as happened to the Member States as well. Even though there are some constraints arisen from the European integration for the local governments, the European integration also opens new intra/extra-State channels of local participation to the decision-making processes in different arenas to be actualised by passionate ones. 


\section{Bibliography:}

- Baun M. and Dan Marek, 'Regional Policy and Decentralization in the Czech Republic', 2006, Regional and Federal Studies, 16(4), p. 409-428.

- Callanan, M. "Domestic governance arrangements and Europeanization: The case of central-local relations in England, Ireland and Denmark", 2010, Comparative European Politics, 10, p. 399-420.

- Committee of the Regions, White Paper on Multilevel Governance, 30 November 2009 (http://web.cor.europa.eu/epp/Ourviews/Documents/White\%20Paper\%20on\%20MLG .pdf), last visited 12.08.2015.

- Christiansen T. and P. Lintner, 'The Committee of the Regions after 10 Years: Lessons from the Past and Challenges for the Future', 2005, Eipascope, Bulletin No. 2005/1, p. 713.

- D'Atena, A. 'Participation of Regional and Local Authorities in the Preparatory Phase of European Policy Making - European Side' in The Committee of the Regions, Procedures for Local and Regional Authority Participation in European Policy Making in the Member State, CoR Studies E- 1 12005, Brussels, January 2005.

- De Rooij, R. 'The Impact of the European Union on Local Government in the Netherlands', 2002, Journal of European Public Policy, 9(3), p. 447-467.

- Fleurke, F. and R. Willemse, 'Effects of the European Union on Sub-National DecisionMaking: Enhancement or Constriction?', 2007, European Integration, 29(1), p. 69-88.

- Guderjan, M. 'Local Government and European Integration - Beyond Europeanisation?' 2012, Political Perspectives, 6(1), p. 105-128.

- Guderjan, M. 'Theorising European Integration of Local Government - Insights from the Fusion Approach', 2015, Local Government Studies, http://dx.doi.org/10.1080/03003930.2015.1057277, p. 1-19.

- Hessel, B. 'European Integration and Supervision of Local and Regional Authorities Experiences in the Netherlands with Requirements of European Community Law', 2006, Utrecht Law Review, 2(1), p. 91-110.

- Hooghe, L. and G. Marks, "Europe with the Regions": Channels of Regional Representation in the European Union", 1996, The Journal of Federalism, 26(1), p. 73-91.

- Hooghe, L. and G. Marks, Multilevel Governance and European Integration, Oxford, Rowman \& Littelfield Publishers, 2001.

- Jeffrey, C. 'Sub-National Mobilization and European Integration: Does It Make Any Difference?', 2000, Journal of Common Market Studies, 38(1), p. 1-23. 
- John, P. 'The Europeanisation of Sub-national Governance', 2000, Urban Studies, 37/5-6, p. 877-894.

- John, P. Local Governance in Western Europe, London, Sage Publications, 2001.

- Kaiser, R. 'Local Governments and the European Union' in M. P. van der Hoek, Handbook of Public Administration and Policy in the European Union, Boca Raton, Taylor \& Francis, 2005 .

- Kern, K. and H. Bulkeley, 'Cities, Europeanization and Multi-level Governance: Governing Climate Change through Transnational Municipal Networks', 2009, Journal of Common Market Studies, 47(2), p. 309-332.

- Ladrech, R. 'Europeanization of Domestic Politics and Institutions: The Case of France', 1994, Journal of Common Market Studies, 32(1), p. 69-88.

- Loughlin, J. 'Conclusions: The Transformation of Regional and Local Democracy in Western Europe', in J. Loughlin, Subnational Democracy in the European Union : challenges and opportunities, Oxford, Oxford University Press, Oxford, 2004.

- Longo, M. '(E)merging Discourses: Local and Regional Governance in Australia and the European Union', 2011, The University of Tasmania Law Review, 30(2), p. 21-50.

- Panara, C. and M. Varney, 'Introduction - Local Government in the EU Layered System of Governance' in C. Panara and Micahel Varney (eds), Local Government in Europe, The 'fourth level' in the EU multilayered system of Governance, London and Newyork, Routledge, 2013.

- Panara, C. The Sub-national Dimension of the EU - A Study of Multilevel Governance, Cham, Springer, 2015.

- Persson, W. 'Sweden - Local government in Sweden: Flexibility and Independence in a Unitary State' in C. Panara and M. Varney, Local Government in Europe - The 'Fourth Level in the EU Multi-Layered System of Governance, London and New York, Routledge, 2013.

- Risse, T., M. G. Cowles and J. Caporaso, 'Europeanization and Domestic Change: Introduction' in M. G. Cowles, J. Caporaso and T. Risse, Transforming Europe Europeanization and Domestic Change, Ithaca, Cornell University Press, 2001.

- Sutcliffe, J. and M. Kovacev, 'Scottish Local Governments in the European Union: A Deepening Relationship within a Multi-Level Governance Setting', 2005, (http://www.cpsa-acsp.ca/papers-2005/Sutcliffe.pdf), last visited 12.08.2015.

- Tatar, M. 'The Impact of the European Union on Sub-National Mobilization in A Unitary State: The Case of Estonia', 2011, Journal of Baltic Studies, 42(3), p. 379-407. 
- Wallace, H. 'EU Enlargement: A Neglected Subject' in M. G. Cowles and M. Smith (eds.), The State of the European Union - Vol. 5 - Risks, Reform, Resistance, and Revival, Oxford, Oxford University Press, 2000.

- Van Bever, E. and T. Verhelst, 'Towards a More Active Approach of Local Level Europeanization - Discussing Horizontal and Bottom-up Europeanization in Flemish Local Government', Paper Submitted for Presentation at the 63rd Political Studies Association Annual Conference 25-27 March 2013, Cardiff.

- Van den Brande, K. H. Bruyninckx and S. Happaerts, 'Introduction' in H. Bruyninckx, S. Happaerts, K. Brande, K. van den Brande (eds.) Sustainable Development and Subnational Governments Policy-Making and Multi-Level Interactions, UK, Palgrave, 2012.

- Van der Heiden, N. 'A Multi-level Governance Analysis of Urban Foreign Policy - The Role of the EU in City-to-City Cooperation', paper presented at the conference "the road to Europe: Main Street or Backward Alley for Local Governments in Europe", Ghent, 30 April 2010, (http://www.zora.uzh.ch/44096/1/Paper Ghent def NicovanderHeiden1.pdf) last visited 12.08.2015.

- Varney, M. 'United Kingdom - Local government in England: Localism delivered?' in C. Panara and M. Varney, Local Government in Europe - The 'Fourth Level' in the EU MultiLayered System of Governance, London and New York, Routledge, 2013.

- Vetter, A. and N. Kersting, 'Democracy versus efficiency? Comparing local government reforms across Europe' in N. Kersting and A. Vetter (eds.), Reforming Local Government in Europe - Closing the Gap between Democracy and Efficiency, Opladen, Springer, 2003.

\section{Cases:}

- Joined Cases 51/71 to 54/71 International Fruit Company and Others [1971] ECR 1107.

- Case 97/81 Commission v. Netherlands [1982] ECR 1819.

- Joined Cases 227, 228, 229 and 230/85 Commission of the European Communities v. Kingdom of Belgium [1988] ECR 1.

- Joined Cases C-6/90 and C-9/90 Andrea Francovich and Danila Bonifaci and others v. Italian Republic [1991] ECR I-5357.

- Joined Cases C-46/93 and C-48/93 Brasserie du Pêcheur SA v. Bundesrepublik Deutschland and The Queen v. Secretary of State for Transport, ex parte: Factortame Ltd and others [1996] ECR I-1029.

- $\quad$ Case 365/97 Commission v. Italy [1999] ECR I-7773. 
- Case 147/00 Commission v. France [2001] ECR I-2387.

- C-480/06 European Commission v. Federal Republic of Germany (Four Landkreise), [2009] ECR I-4747.

- Case C-156/13 Digibet Ltd and Gert Albers v. Westdeutsche Lotterie GmbH \& Co. OHG, ECLI:EU:C:2014:1756. 